\title{
Pembudayaan Nilai Karakter Dalam Keluarga Di Desa Madwaer Kabupaten Maluku Tenggara Kec Kei Kecil Barat
}

\author{
Susianti Rahakbauw \\ susiantirahakbauw01@gmail.com
}

\begin{abstract}
Forming a good character for a child requires the role of a family. This writing aims to cultivate the values of the character in the family can make the children's characters better. Cultual (Enkulturasi) is the process of studying the values and cultural norms experienced by the individual during his lifetime. The beginning of the process of culture of character value for a child is individually born to know and understand his position and standing, is through the family. This research is the result of field studies using a qualitative research approach with observation and interview methods. Research location in Ohoi Madwaer, district of Kei Kecil Barat, southeast Maluku. The results showed that most parents/families have not committed their roles and responsibilities to cultivate the character values well for the child, due to busy work and other factors, parents are also rude to their children, from the results of the research is also obvious that most of the children in Ohoi Madwaer have a character that is not good, and found that there are values that are focused in applying and doing it in the family The value of religious, honest, discipline and tolerance. These values suffer from the erosion caused by unkind characters that are shown by parents and children in the family environment. Secondly, in connection with this, the value of the character has its relation to PAK, which is embedding and giving and teaching good value to everyone in order to keep the character good.
\end{abstract}

Keyword: Culture, character value, family

\section{Pengantar}

Dewasa ini pendidikan karakter sedang ramai diwacanakan. Selain menjadi bagian dari proses pembentukan akhlak atau kepribadian anak bangsa, pendidikan karakter ini pun diharapkan dapat menjadi fondasi utama dalam meningkatkan derajat dan martabat bangsa Indonesia. Pendidikan dapat mencakup semua perbuatan atas semua usaha dari generasi tua untuk mengalihkan nilai - nilai serta melimpahkan pengetahuan, pengalaman, kecakapan serta ketrampilan kepada generasi selanjutnya sebagai usaha untuk menyiapkan mereka agar dapat memenuhi fungsi hidup mereka baik secara jasmani maupun rohani. Ki Hadjar Dewantara menyebutkan bahwa pendidikan adalah sebagai tuntutan segala kekuatan kodrat yang ada pada anak agar mereka kelak menjadi manusia dan anggota masyarakat yang dapat mencapai keselamatan dan kebahagiaan yang setinggi - tingginya (Kurniawan, 2013).

Sementara itu istilah karakter mengacu pada serangkaian sikap ( attitudes ), perilaku ( behaviors ), motivasi ( motivations ) dan ketrampilan ( skills ). Menurut Zubaedi, karakter meliputi sikap seperti keinginan untuk melakukan hal yang terbaik, kapasitas intelektual seperti kritis dan alasan moral, perilaku seperti jujur dan bertanggung jawab, mempertahankan prinsip-prinsip moral dalam situasi penuh ketidakadilan, kecakapan interpersonal dan emosional yang memungkinkan seseorang berinteraksi secara efektif dalam berbagai keadaan dan komitmen untuk berkontribusi dengan komunitas dan masyarakatnya (Kurniawan, 2013).

Menurut Adisusila (2014) Karkater merupakan nilai - nilai perilaku manusia yang berhubungan dengan Tuhan Yang Maha Esa, diri sendiri, sesama manusia, lingkungan, dan kebangsaan yang terwujud dalam pikiran, sikap, perasaan, perkataan dan perbuatan, berdasarkan norma - norma agama, hukum, tata karma, budaya dan adat istiadat. Individu yang berkarakter baik atau unggul adalah seseorang yang berusaha melakukan hal terbaik terhadap Tuhan yang Maha Esa, dirinya, sesama, lingkungan, bangsa dan Negara dengan mengoptimalkan potensi ( pengetahuan ) dirinya dan disertai dengan kesadaran, emosi, dan perasaannya. Salah satu cara untuk membangun karakter adalah melalui pendidikan. Pendidikan yang ada, baik itu pendidikan di keluarga, masyarakat atau pendidikan formal di sekolah harus menanamkan nilai - nilai untuk pembentukan karakter.

Sejalan dengan proses pengembangan budaya dan karakter bangsa, maka kita perlu melakukan yang namanya upaya - upaya pembudayaan dan penanaman nilai karakter yang baik kepada anak - anak di dalam keluarga. Karena keluarga merupakan bagian yang terkecil dalam masyarakat yang terdiri dari ayah, ibu, dan anakanak (keluarga inti) yang mempunyai hubungan ikatan hukum, biologis, sosial, psikologis, dan 
ekonomi serta dilandasi dengan cinta kasih dan kewajiban.

Keluarga merupakan salah satu lingkungan proses pembudayaan, pengajaran dan penanaman nilai karakter yang dilakukan oleh orang tua secara ( informal) dalam rangka meletakan dasar pengetahuan secara moralitas, etik, spiritualitas bagi anak dalam perkembangannya. Keluarga merupakan wadah sentral di mana anak dibimbing dan diajarkan untuk memaknai diri dan kehidupannya serta memperoleh kekayaan hidup. Setiap orang tua, siapa pun selalu mengharapkan suatu masa depan yang baik bagi anak-anaknya dan karena itu segala upaya dilakukan termasuk upaya pembudayaan serta penanaman nilai karakter kearah yang lebih baik.

Dapat dikatakan bahwa Orang tua atau keluarga adalah sebagai basis utama pembentukan karakter anak dalam keluarganya sendiri, sehingga nilai karakter yang ditanamkan orang tua kepada anak betul-betul dijaga, dipelihara dan harus diaplikasikan dengan baik lewaat sikap, tindakan dan perbuatan sehari-hari. Jika orang tua atau keluraga dalam tanggung jawabnya sendiri tidak menanamkan dan mengajarkan nilai karakter kepada anak-anaknya dari dalam kandungan sampai ia lahir dan dibesarkan maka anak itu akan bertumbuh dengan karakter yang kurang baik dan tidak menghargai nilai-nilai karakter yang ada dalam keluarganya sendiri.

Teladan orang tua juga merupakan aspek penting yang perlu diperhatikan dalam pendidikan karakter di lingkungan keluarga. Dalam keluarga diharapkan terdapat sosok yang dapat dijadikan teladan terutama bagi anak dan tentunya yang paling berperan adalah orang tua sebagai sosok model manusia yang diharapkan. Maksudnya, jika orang tua mengaharapkan anaknya jujur maka jadilah orang tua yang jujur, begitu pula jika mengharapkan supaya anaknya rajin maka jadilah orang tua yang rajin, dan jika mengharpkan anaknya disiplin maka jadilah orang tua yang disiplin. Contoh nyata dari orang tua ini sangat penting artinya sebagai percontohan dan figur yang baik bagi anak.

Ditinjau dari perkembangan karakter anak di dalam kehidupan bermasyarakat terlebih khusus dalam kehidupan keluarga telah teridentifikasih bahwa kencenderungan anak-anak dalam keluarga pada umumnya memiliki karakter yang kurang baik. berdasarkan permasalahan yang terjadi pada karakter anak usia $11-17$ tahun, seringkali saya temukan di dalam kehidupan masyarakat Madwaer dengan Sikap karakter mereka yang kurang baik yang biasanya ditunjukan adalah tidak dengar - dengaran terhadap orang tua, malas, sering kali mengucapkan kata-kata kotor, kurang adanya sopan santun, menantang orang tua dengan ingin memukul orang tuanya sendiri, sampai dengan pelanggaranpelanggaran moral yang merusak karakter yaitu merokok dan miras. Hal-hal ini dengan tidak disadari dapat merusak karakter sehingga ketika tidak diatasi maka karakter anak-anak semakin rusak dan bahkan sampai pelanggaran-pelanggaran moral dengan skalah besar yang dapat merusak karakter seperti, penyelagunaan obat-obat terlarang, dan seks bebas.

Ada beberapa permasalahan yang terjadi oleh orang tua di desa Madwaer adalah seringkali bersikap kasar terhadap anak, malas beribadah, tidak memperhatikan jam belajar anak, dan jarang sekali dalam menasehati anak. Sekecil apapun permasalahan-permasalahan ini terus dibiarkan maka satu ketika akan susah untuk dapat membentuk karakter anak dengan baik. Karena sudah dari awal orang tua sendiri tidak memperhatikan anak dengan baik bahkan menasehati anak juga jarang dilakukan. Jika orang tua menunjukan hal yang buruk maka anak juga akan melakukan hal buruk, tetapi jika orang tua menunjukan hal baik anak juga akan melakukan hal yang baik sesuai dengan jejak yang di tunjukan oleh orang tuanya sendiri. Karena itulah sebuah peran dan tanggung jawab orang tua dalam membina serta menanamkan nilai-nilai karakter yang baik dalam keluarga.

Oleh sebab itu perlu adanya pembudayaan nilai karakter dalam keluarga. Pembudayaan nilai karakter dalam keluarga dapat membawa perubahan karakter yang baik bagi setiap orang dalam keluarganya.

Berdasarkan uraian dalam latar belakang masalah di atas, maka masalah yang hendak diteliti adalah: a) apa bentuk - bentuk pembudayaan nilai karakter dalam keluarga di Desa Madwaer ? b) apa relevansi nilai - nilai karakter dalam keluarga di desa Madwaer terhadap PAK

Penelitian ini secara teoritis diharapkan dapat memberikan kontribusi pada lembaga IAKN Ambon khususnya jurusan PAK guna tetap melakukan berbagai riset penelitian yang membangun dunia pendidikan dalam keluarga maupun sekolah. dan secara praktis dapat memberikan pengetahuan yang positif kepada masyarakat di Desa Madwaer dan menjadi pedoman untuk membentuk karakter anak di dalam keluarga dengan baik. 
PEMBUDAYAAN NILAI KARAKTER DALAM KELUARGA DI DESA MADWAER

Penelitian ini bukan sesuatu yang baru, karena sudah ada kajian - kajian serupa sebelum. Berikut ini dikemukakan beberapa penelitian sebelum terkait masalah yang dikaji. "Pertama" Yane. E. S. Mattinahoruw meneliti tentang "Peran Orangtua dalam Membentuk Karakter Anak Usia Remaja di jemaat GPM Imanuel Karpan " dan disimpulkan bahwa keluarga sebagai tempat yang utama untuk anak belajar dan mengenal jati diri mereka, disamping itu peran orang tua dalam membentuk karakter anak usia remaja adalah memberi kasih sayang, memberi dorongan, menjadi sahabat, mendidik, menasihati, dan menanamkan nilai - nilai agama dan moral. Hasil penelitiannya menunjukan bahwa anak remaja di Jemaat GPM Imanuel Karpan sering memunculkan karakter yang kurang baik yang kenyataannya cenderung merugikan dirinya. Oleh sebab itu dalam hasil penelitiannya menunjukan bahwa peran orang tua dalam keluarga sangat dibutuhkan di jemaat GPM Imanuel Karpan dengan demikian masa depan anak menjadi masa depan orang tua dan lingkungan. "Kedua" Yanestans H. Unitly mengkaji tentang “ Peran Guru PAK dalam Menanamkan Nilai - Nilai Karakter bagi Siswa di SD Negeri 65 Ambon". Peran guru bukan hanya mengajar atau memberi materi. Peran guru PAK dalam menanamkan karakter yang baik sangatlah penting.. Peran guru PAK dalam menanamkan nilai-nilai karakter bagi siswa di SD Negeri 65 Ambon dalam Hasil penelitian ditemukan guru mampu untuk menanamkan nilai-nilai karakter pada masingmasing anak yang berbeda karakternya. Dan oleh sebab itu dalam hasil penelitiannya menunjukan bahwa pemahaman Kepala sekolah dan guru dalam menanamkan nilai-nilai karakter bagi siswa di SD Negeri 65 Ambon sudah baik. Peran guru PAK dalam menanmkan nilai-nilai karakter bagi siswa di sekolah yaitu dengan mengetahui karakter dari setiap siswa yang berbeda-beda dan membuat pendekatan dengan siswa supaya menuntun karakter anak lebih baik.

\section{Tinjauan Literatur}

Budaya dan Proses Pembudayaan ( Enkulturasi )

Kebudayaanlah yang membedakan manusia dengan hewan. Dalam ruang lingkup kebudayaan, manusia mengembangkan hidup individual dan sosialnya, dalam rangka pemenuhan martabat kemanusiaannya.

Kebudayaan adalah suatu cara hidup bersama, cara khas manusia dalam menyesuaikan diri dengan lingkungan alam, dan merupakan
KABUPATEN MALUKU TENGGARA KEC KEI KECIL BARAT strategi manusia dalam memenuhi kebutuhankebutuhan hidupnya. Seperti dikatakan oleh Chirstopher Dawson dalam (Maran, 2007), kebudayaan adalah suatu komunitas berangkap empat, yakni komunitas kerja, komunitas pikiran, komunitas tempat dan komunitas darah ( ras ). Dalam interaksi ini, manusia berperan sebagai faktor aktif-kreatif, karena memiliki akal budi dan kebebasan sedangkan lingkungan alam elemenelemen material menjadi kondisi bagi manusia untuk mencipatakan kebudayaan. Karena kebudayaan adalah hasil interaksi antara manusia dan lingkungan alam yang bersifat material, maka kebudayaan bukanlah suatu proses fisik semata, juga bukan konstruksi ideal belaka. Di dalam kenyataan, kebudayaan adalah suatu kehidupan yang bersifat meyeluruh mulai dari akarnya di tanah dan dalam kehidupan sederhana kaum penggembala, nelayan dan sebagainya sampai ke taraf perkembangannya yang lebih tinggi dalam prestasi-prestasi yang menakjubkan para seniman dan filsuf.

Para pakar antropologi budaya Indonesia umumnya sependapat bahwa kata kebudayaan berasal dari bahasa sansekerta yaitu buddayah adalah bentuk jamak dari buddhi yang berarti budi atau akal. Secara etimologis kata kebudayaan berarti hal-hal yang berkaitan dengan akal. Namun ada pula anggapan bahwa kata budaya berasal dari kata majemuk budi-daya yang berarti daya dari budi atau daya dari akal yang berupa cipta, karsa dan rasa. Sir Edward B. Taylor menggunakan kata kebudayaan untuk menunjuk " keseluruhan kompleks dari ide dan segala sesuatu yang dihasilkan manusia dalam pengalaman historisnya ". Termasuk di sini ialah pengetahuan, kepercayaan, seni, moral, hukum, kebiasaan dan kemampuan serta perilaku lainnya yang diperoleh manusia sebagai anggota masyarakat (Maran,2007).Rumusan yang hampir sama dikemukakan pula oleh Robert $\mathrm{H}$. Lowie dalam (Maran,2007) mengatakan kebudayaan adalah segala sesuatu yang diperoleh individu dari masyarakat, mencakup kepercayaan, adat - istidat, norma - norma artistic, kebiasaam makan, keahlian yang diperoleh bukan karena kreativitasnya sendiri melainkan merupakan warisan masa lampau yang didapat melalui pendidikan formal maupun informal. Sedangkan menurut Keesing, kebudayaan adalah totalitas pengetahuan manusia, pengalaman yang terakumulasi dan yang ditransmisikan secara sosial atau singkatnya, kebudayaan adalah tingkah laku yang diperoleh melalui proses sosialisasi (Maran, 2007). Dan menurut Koentjaraningrat dalam (Maran,2007), kebudayaan adalah 
keseluruhan system gagasan, tindakan, dan hasil karya manusia dalam rangka kehidupan masyarakat yang dijadikan milik diri manusia dengan belajar.

Dengan memahami konsep kebudayaan, maka kita perlu mengetahui bahwa setiap kebudayaan mempunyai unsur - unsur dasar yaitu: kepercayaan, nilai, norma, dan sanksi, simbol, teknologi, bahasa dan kesenian.

\section{Kepercayaan}

Kepercayaan berkaitan dengan pandangan tentang bagaimana dunia ini beroperasi. Kepercayaan itu bisa berupa pandangan pandangan atau interpretasi - interpretasi tentang masa lampau, bisa berupa pennjelasan - penjelasan tentang masa sekarang,bisa berupa prediksi prediksi tentang masa depan, dan bisa juga berdasarkan akal sehat, kebijaksanaan yang dimiliki suatu bangsa, agama, ilmu pengetahuan, atau suatu kombinasi antara semua hal tersebut.

2. Nilai

Jika kepercayaan menjelaskan apa itu sesuatu, nilai menjelaskan apa yang seharusnya terjadi. Nilai itu luas, abstrak, standar kebenaran yang harus dimiliki, yakni diinginkan dan yang layak dihormati. Meskipun mendapat pengakuan luas, nilai - nilai pun jarang ditaati oleh setiap anggota masyarakat. Namun inilah yang menentukan suasana kehidupan kebudayaan dan masyarakat. Tak boleh dilupakan bahwa manusia dan masyarakat mana pun umumnya memperjuangkan dan membela nilai - nilai dasar yang sama, seperti cinta, kebaikan, keindahan, keadilan, persaudaraan, persahabatan, persatuan dan perdamaian. Perjuangan ini menunjukan bahwa manusia pada dasarnya memiliki martabat dan cita cita yang sama.

3. Norma dan sanksi.

Norma adalah suatu aturan khusus, atau seperangkat peraturan tentang apa yang harus dan apa yang tidak harus dilakukan oleh manusia. Norma mengungkapkan bagaimana manusia seharusnya berperilaku atau bertindak. Norma adalah standar yang ditetapkan sebagai garis pedoman bagi setiap ativitas manusia lahir dan kematian, bercinta dan berperang, apa yang harus dimakan dan apa yang harus dipakai, kapan dan dimana orang bisa bercanda melucu dan sebagainya.

Namun demikian, secara aktual perilaku manusia dapat menyimpang dari norma - norma yang ada. Lagi pula, orang atau masyarakat dapat memiliki standar - standar perilaku yang berbeda atau bahkan saling bertentangan.

Jika norma - norma adalah garis pedoman , sanksi - sanksi merupakan kekuatan penggeraknya.
Sanksi adalah ganjaran ataupun hukuman yang memungkinkan orang mematuhi norma.

4. Bahasa

Bahasa adalah gudang kebudayaan. Pelbagai arti yang diberikan manusia terhadap objek - objek, peristiwa - peristiwa dan perilaku merupakan jantung kebudayaan. Dan merupakan sarana utama untuk menangkap, mengkomunikasikan, mendiskusikan, mengubah dan mewariskan arti arti ini kepada generasi baru.

\section{Proses Pembudayaan ( enkulturasi )}

Pembudayaan ( Enkulturasi ) adalah proses mempelajari nilai dan norma kebudayaan yang dialami individu selama hidupnya. Dalam proses ini seorang individu mempelajari dan menyesuaikan alam pikiran serta sikapnya dengan adat-istiadat, sistem norma, serta peraturan-peraturan yang hidup dalam kebudayaannya. Seorang individu dalam hidupnya juga sering meniru dan membudayakan berbagai macam tindakan setelah perasaan dan nilai budaya yang memberi motivasi akan tindakan meniru itu telah diinternalisasi dalam kepribadiannya. Anak-anak menghabiskan masamasa awal kehidupan bersama keluarga dan memperoleh refleksi nilai dan pola perilaku keluarganya. Selanjutnya, kepada mereka ditunjukkan nilai-nilai dan pola-pola perilaku masyarakat. Anak-anak mempelajari norma-norma masyarakat melalui keluarga dan teman-teman bermain. Selain itu, mereka meniru berbagai macam tindakan yang terdapat dalam masyarakat. Kadangkadang, orang tua mendorong anaknya supaya berperilaku sesuai dengan kehendak masyarakat dengan memberikan pujian dan menghukum mereka bila berperilaku menyimpang.

Menurut Hoebel (2018) pembudayaan adalah kondisi saat seseorang secara sadar atau pun tidak sadar mencapai kompetensi dalam budayanya dan menginternalisasi budaya tersebut. Hasil dari proses pembudayaan adalah identitas, yaitu identitas pribadi dalam sebuah kelompok masyarakat. Masyarakat berusaha untuk membuat seseorang memiliki rasa bertanggung jawab. Proses pembudayaan terkadang mengasingkan sebagian orang. Hal tersebut bertujuan untuk membuat mereka menjadi bertanggung jawab. Proses pembudayaan memiliki dua aspek utama, yaitu pendidikan formal dan informal. Pendidikan formal dilakukan melalui sebuah lembaga pendidikan, sedangkan pendidikan informal yang disebut sebagai child training dilakukan oleh keluarga dan teman. 
PEMBUDAYAAN NILAI KARAKTER DALAM KELUARGA DI DESA MADWAER

Menurut Shadily (1987) Proses pembudayaan terjadi ketika mereka bergaul dengan masyarakat dari mulai anak-anak hingga tua. Melalui proses tersebut, seseorang belajar menghormati simbol bangsa dari menyanyikan lagu kebangsaan di sekolah. Ia juga belajar dengan siapa ia mungkin melakukan kekerasan fisik (pegulat). Selain itu, ia menjadi sadar akan hak dan kewajiban dirinya dan orang lain.

Manan (1989) menyebutkan pembudayaan dalam arti luas, pendidikan termasuk ke dalam proses umum, di mana seseorang anak bertumbuh diinisiasikan ke dalam cara hidup dari masyarakatnya. Pendidikan mencakup setiap proses, kecuali yang bersifat genetik, yang menolong membentuk pikiran, karakter, atau kapasitas fisik seseorang. Proses tersebut berlangsung seumur hidup, karena kita harus mempelajari cara berpikir dan bertindak yang baru dalam perubahan besar dalam hidup kita. Dalam arti sempit pendidikan, adalah penanaman pengetahuan, keterampilan dan sikap pada masing-masing generasi dalam menggunakan pranata-pranata, seperti sekolahsekolah yang sengaja diciptakan untuk tujuan tersebut. Istilah pendidikan juga berarti disiplin ilmu (termasuk psikologi, sosiologi, sejarah, dan filosofi pendidikan).

Semiawan (2007) menyebutkan bahwa pendidikan itu merupakan "proses membebaskan diri", di mana insan manusia memperoleh peluang mengaktualisasi diri secara optimal "to become what he is capable of", suatu upaya untuk memberdayakan manusia sesuai kemampuan yang ada padanya dan sesuai pilihannya sendiri. Ini adalah suatu pengembangan kemampuan manusia (human capacity development, $\mathrm{HCD}$ ). Pernyataan ini menggaris bawahi bahwa pendidikan membantu manusia untuk merubah dan mengembangkan dirinya serta meng-enkulturasi diri bukan mengdiisolasikan diri.

Menurut Herskovits (2004), pembudayaan berasal dari aspek - aspek dari pengalaman belajar yang memberi ciri khusus atau yang membedakan manusia dari makhluk lain dengan menggunakan pengalaman-pengalaman hidupnya. Proses pembudayaan bersifat kompleks dan berlangsung sepanjang hidup, tetapi proses tersebut berbeda-beda pada berbagai tahap dalam lingkaran kehidupan seseorang. Pembudayaan terjadi tanpa disadari dan secara agak dipaksakan selama awal masa kanakkanak tetapi ketika mereka bertambah dewasa akan belajar secara lebih sadar untuk menerima atau
KABUPATEN MALUKU TENGGARA KEC KEI KECIL BARAT menolak nilai-nilai atau anjuran-anjuran dari masyarakatnya..

Pembudayaan juga tidak hanya dilakukan sejak seorang anak lahir, akan tetapi dimulai dari dalam kandungan. Begitu anak lahir, dimulailah secara langsung proses pembudayaan secara otomatis. Memandikan anak dua kali dalam sehari atau hanya sekedar dilap dengan air ketika badannya sedikit hangat atau cuaca dingin. Ini menjadikan sang anak akan terbiasa untuk selalu mandi minimal dua kali dalam sehari. Kemudian proses pembudayaan dilanjutkan dengan mengenal atau dimulainya sang anak untuk berpakaian, berawal dengan dibungkus kain (dibedong). Dilanjutkan dengan mengkhususkan ciri berpakaian untuk anak laki-laki dan untuk anak perempuan.

Pembudayaan dalam hubungannya dengan nilai karakter dalam keluarga sendiri adalah keduanya memberikan kontribusi yang baik dalam kehidupan keluarga di mana dengan adanya pembudayaan maka nilai-nilai karakter yang ada di dalam keluarga terus dikembangkan, dipelajari, dijaga, ditanamkan dan diterapkannya demi dan untuk memperbaiki karakter dalam diri setiap orang

\section{Penanaman Nilai - Nilai Karakter di Lingkungan Keluarga.}

Masa-masa dominan dalam pembentukan karakter dan kepribadian anak ada di dalam keluarga. Fase tersebut mulai dari periode kanakkanak hingga periode dewasa awal. Pada fase tersebut anak memiliki kecenderungan untuk mengikuti atau meniru tata nilai dan perilaku disekitarnya, pengambilan pola perilaku, dan nilai nilai baru serta tumbuhnya idealism untuk pemantapan identitas diri. Jika pada fase itu dilakukan proses penanaman nilai - nilai moralitas yang terangkum dalam pendidikan karakter secara sempurna, akan menjadi fondasi dasar sekaligus warna kepribadian anak ketika dewasa kelak.

Penanaman nilai-nilai karakter di lingkungan keluarga dapat mengacu pada sembilan nilai. Sembilan nilai yang disarankan untuk pendidikan karakter beserta strategi internalisasi karakter pada anak dalam lingkungan keluarga menurut Adisusolo (2014), adalah sebagai berikut:

\section{Religius}

Nilai religius pada anak tidak cukup diberikan melalui pelajaran, pengertian, penjelasan, dan pemahaman. Kemudian, membiarkan anak berjalan sendiri. Penanaman nilai religius pada anak memerlukan bimbingan yaitu usaha untuk menuntun, mengarahkan sekaligus mendampingi 
anak dalam hal-hal tertentu, terutama ketika anak merasakan ketidakberdayaannya atau ketika anak sedang mengalami suatu masalah yang dirasakannya berat. Maka, kehadiran orang tua dalam membimbingnya akan sangat berarti dan berkesan bagi anak - anaknya. Keteladan orang tua juga merupakan hal penting dalam penanaman nilai religius pada anak. Anak cenderung mengidentifikasikan dirinya dengan orang tua, baik pada ibu atau pun ayahnya. Segala ucapan, gerak gerik atau tingkah laku keseharian orang tua akan diperhatikan oleh anak dan cenderung akan diikuti, paling tidak akan dikritsi oleh anaknya. Orang tua yang rajin beridah, akan menyuruh anakya untuk rajin beridah. Orang tua yang selalu berbicara dan perprilaku santun akan lebih mudah mengingatkan anaknya untuk berbicara dan berprilaku santun. Orang tua yang mencerminkan pengalaman nilai nilai religius ini akan menjadi contoh bagi anak anaknya yang suatu saat akan muncul dalam perilaku keseharian anak - anaknya.

2. Jujur

Kejujuran merupakan hal yang penting, namun sedikit orang tua yang peduli akan kejujurananaknya. Kejujuran di saat dewasa tak lepas dari kejujuran yang ditanamkan saat masi anak-anak. Ketika sejak anak-anak sudah ditanamkan kejurjuran maka sampai dewasa kejujuran itu akan tertanam dalam jiwa si anak.

Beberapa hal yang dapat dilakukan orangtua untuk menumbuhkan kejujuran pada anak, diantaranya sebagai berikut.:

a. Jangan membohongi anak. Kadangkala orang tua membohongi anak demi sesuatu hal, misalnya agar anaknya tidak menangis dijanjikan suatu barang, namun ketika anaknya sudah diam barang tersebut tidak diberikan. Dengan demikian, anak akan berpikir ternyata dia di bohongi dan hal itu akan tetap membekas hingga dia dewasa dan ketika dewasa akan beganti membohongi karena sejak kecil telah diajari berbohong oleh orang tuanya.

b. Hargai kejujuran. Sedikit sekali orang tua yang menghargai kejujuran anaknya sehingga ketika si anak berusaha jujur tidak diberikan ganjaran atas kejujurannya. Jika demikian maka kejujuran dianggap hal yang tidak penting sehingga akan mengabaikan kejujuran tersebut.

c. Tanamkan kejujuran sejak dini. Ketika anak sudah terbiasa jujur sejak kecil maka nilai nilai kejujuran tersebut akan terpola secara otomatis dalam pribadi anak - anak. Dengan demikian si anak akan terbiasa jujur hingga dewasa.

d. Selalu motivasi anak berlaku jujur. Seorang anak memerlukan bimbingan dan motivasi secara bersinergi agar kejujuran yang ditanamkan pada anak tetap berada dalam diri anak.

3. Toleransi

Orangtua perlu mendidik anak tentang apa artinya toleransi dan rasa hormat kepada orang lain yang bisa saja menganut pemahaman berbeda darinya. Toleransi adalah kemampuan seseorang untuk menerima perbedaan dari orang lain. Hal ini baru bisa dilakukan oleh seseorang jika sudah merasakan dan memahami keterikatan, regulasi diri, afiliasi, dan kesadaran. Ketika ia sudah mampu menjaga hubungan yang sehat dan dekat, merasa berada dalam sebuah kelompok serta merasa nyaman di dalamnya, juga mampu menilai sebuah situasi, melihat kekuatan, kebutuhan dan ketertarikan orang lain. Rasa hormat merupakan kemampuan untuk melihat serta merayakan nilai di dalam diri kita dan orang lain. Butuh emosi, kognitif, serta kematangan sosial. Membangun rasa menghoramti adalah tantangan seumur hidup, namun prosesnya dimulai sejak dini.

Berikut adalah beberapa aspek yang perlu diingat oleh orangtua dalam mengajarkan toleransi dan rasa hormat pada orang lain kepada anak.

a. Buat anak merasa bahwa dirinya spesial, aman, dan dicintai. Jangan mengehemat kata-kata pujian saat ia memang melakukan hal yang baik dan membanggakan. Anak yang dikasihi akan belajar mengasihi orang lain.

b. Ciptakan sarana belajar ditempat baru, orang orang baru dan budaya berbeda. Paparkan pada anak pada banyaknya perbedaan di dunia ini. Ada banyak buku, makanan, efen budaya, dan perayaan untuk dikenalkan pada anak. Ajakan anak ke acara - acara budaya, kenalkan ia akan ritual agama lain. Ajar anak untuk berinteraksi dengan orang yang berbeda darinya dengan cara yang sehat. Pahamkan pada anak bahwa tidak ada yang salah dari perbedaan, asal saling menghormati dan toleransi.

c. Gunakan komentar positif untuk membentuk sikap si anak.

d. Tunjukan caranya. Anak akan belajar untuk bersikap lebih baik, sensitive, dan menghormati orang lain dengan melihat orangtuanya, misalnya dalam berdiskusi, berpikiran terbuka, dan menghargai orang lain ( tidak pula 
PEMBUDAYAAN NILAI KARAKTER DALAM KELUARGA DI DESA MADWAER

menjelek-jelekkan orang lain karena golongannya berbeda dengan anda ).

4. Disiplin .

Berikut beberapa hal yang perlu diperhatikan orangtua dalam menanamkan nilai-nilai disiplin pada anaknya. a) Orangtua harus konsisten ( tidak berubah ), yaitu ada kesepakatan antara kedua orangtua ( ayah dan ibu ) sehingga setiap tindakan dalam menanamkan kedisplinan tidak berubah-ubah. b) Berikan aturan yang sederhana dan jelas sehingga anak mudah melakukannya. c) Jangan menegur anak dihadapan orang lain karena hal itu akan membuat anak merasa malu sehingga tetap mempertahankan tingka-laku tersebut. d) alasan dan tata tertib yang dilakukan itu perlu dijelaskan pada anak sehingga anak melakukannya dengan penuh kesadaran.e) Hadiah berupa ujian, penghargaan, barang atau kegiatan ( misalnya memperbolehkan bermain, nonton TV, dan lain - lain ) diberikan apabila anak melakukan perilaku positif. Hal tersebut akan menumbuhkan rasa percaya diri. f) Orang tua harus berhati - hati dalam memberikan hukuman, jangan smpai menyakiti fisik atau jiwa anak. Hukuman tidak dapat dibrikan terhadap anak dibawah usia 3 tahun, apa lagi memukulnya. Hukuman merupakan “ pilihan terakhhir ", lebih baik memuji perbuatannya yang benar dari pada menghukum kesalahannya. Demikian pula dalam menghukum anak, sebaiknya hindari emosi yang berlebihan. g) Jangan terlalu kaku dalam menegakkan disiplin, sesuaikan dengan keadaan situasi anak. h) Sebaiknya anak dilibatkan dalam setiap membuat tata - tertib sehingga anak merasa dihargai dan diakui dalam keluarga. i) Bersikap tegas bukan berarti bersikap kasar baik dalam tindakan fisik atau perbuatan.

5. Mandiri .

Kemandirian merupakan salah satu modal penting bagi anak-anak untuk bertahan hidup kelak saat mereka dewasa. Karenannya mengajarkan kemandirian merupakan salah satu tanggung jawab terpenting yang dimiliki orangtua untuk mulai menanamkan kemandirian pada anak-anak. Berikut beberapa hal yang dapat dilakukan orangtua untuk mulai menanamkan kemandirian pada anak-anak.

a. Sediakan pilihan. Saat anak-anak berusia dua tahun, mereka mulai mengembangkan kemandirian. Saat anak semakin bertambah dewasa izinkan dia membuat keputusankeputusan yang lebih sulit, seperti memilih pakaiannya sendiri. Membiarkan anak-anak mengontrol beberapa bagian dalam hidupnya akan memupuk kepercayaan diri dan kemandirian.
KABUPATEN MALUKU TENGGARA KEC KEI KECIL BARAT

b. Tetapkan waktu tidur malam yang rutin. Belajar tidur sendiri di malam hari mungkin sulit bagi anak-anak, tapi merupakan sebuah bagian yang penting untuk menjadi mandiri. Anak-anak harus belajar untuk tidur sendiri tanpa orangtuanya. Bila orangtua menemani anak sampai anak tertidur atau mengizinkan dia tidur di kamar, akan semakin sulit bagi anak itu untuk mandiri. Buatlah sebuah rutinitas yang sehat saat malam hari untuk mempersiapkan anak untuk tidur. Mungkin pada awalnya anak akan mencoba untuk melawan rutinitas ini, tapi kita harus berusaha bersikap tegas dan konsisten.

c. Jangan melakukan sesuatu untuk anak bila dia mampu melakukannya sendiri. Saat orangtua terus - menerus melakukan hal-hal yang sebenarnya bisa dilakukan sendiri untuk anak, maka secara tak langsung orangtua sedang mengajarinya untuk tidak mandiri. Untuk membangun kemandirian, biarkan dia mencoba melakukan sesuatu untuk dirinya sendiri sekalipun gagal.

\section{Demokratis}

Kata demokrasi memang gampang diucapkan, tetapi di sana sini terjadi penyimpangan. Hal itu lantaran perilaku demokratis membutuhkan prasyarat, kerelaan mendengarkan dan menghargai pendapat orang lain. Oleh karena itu, sikap demokratis harus dipupuk sejak anak usia dini. Dalam hal ini orangtua harus selalu mau mendengarkan pendapat anak dan sekaligus menyadari bahwa tidaklah selalu pendapat orang dewasa yang harus menang.

Di indonesia, banyak orang tua yang suka memaksakan kehendak pada anak. Hal yang dikhawatirkan, harus menurut apapun kata orangtua bisa menghambat kemandirian anak. Oleh karena itu, sejak kecil anak hendaknya dibiasakan berdialog. Kalau kemudian pendapatnya berharga, orangtua harus menghargai. Selain itu menumbuhkan sikap demokratis dapat lewat pendidikan kedisplinan.

7. Peduli lingkungan

anak merupahkan generasi penerus yang mewariskan keberlangsungan bumi. Ketidakpedulian orangtua terhadap kelestarian lingkungan, bukan hanya mewariskan kondisi lingkungan yang buruk, melainkan pula menciptakan generasi penerus yang tak ramah lingkungan. Oleh karena kepedulian orangtua saja masih belum cukup, orangtua juga perlu mendidik anak sedini mungkin agar mereka meneganal lingkungan. Dengan demikian, bumi tetap menjadi 
tempat yang nyaman untuk kehidupan. Tanamkna hakikat alam terlebih dahulu sebelum orangtua mendorong kecintaan anak terhadap lingkungan. Anak memahami bumi beserta isinya merupakan ciptaan dan anugerah Tuhan, yang dibeikan kepada manusia agar dimanfaatkan sebaik - baiknya sebagai pendukung kehidupan. Agar manfaatnya maksimal maka alam harus dijaga dan dipelihara.

Kerusakan alam akibat ulah manusia akan menimbulkan dampak yang merugikan. Jika hal ini tertanam dalam pola pikir anak, orangtua akan lebih mudah memberi teladan. Misalnya orangtua senantiasa membiasakan diri membuang sampah pada tempatnya, mendidik anak terkait dengan kemerdekaan akal budi dari ketidaktahuan, termasuk memberi jalan agar anak lebih beradap dalam memperlakukan lingkungan hidupnya.

Sikap kecintaan lingkungan anak merupakan hasil proses pendidikan yang dialaminya, baik dari sekolah maupun orangtua. Karena itu, pendidikan yang paling efektif adalah keteladanan dari orangtua. Untuk itu, orangtua perlu membiasakan pola hidup bersih, sehat, dan ramah lingkungan dalam keluarganya. Tanamkan pola kesadaran, menjaga alam merupakan bagian dari ibadah, yang memberi manfaat bagi peningkatan kualitas. Anak belajar dengan meniruh dan mencontoh.

Kepedulian kepada kelestarian lingkungan perlu dilakukan sejak dini karena pengaruh pada usia dini merupakan dasar pembentukan karakter anak. Mengajarkan cinta lingkungan juga akan menumbuhkan sikap bersyukur. Umumnya, anak yang mencintai alam, cenderung berhati lembut dan juga mengasihi sesama.

Meningkatkan pemahaman anak tentang perlunya menjaga lingkungan, dapat juga dilakukan orangtua dengan berdiskusi mengenai lingkungan bersama anak. Diskusi dapat diarahkan untuk mengetahui penyebab dari perilaku masyarakat yang berakibat pada masalah global lingkungan. Berikan penjelasan sesuai kemampuan pemahaman anak. Sebaiknya gunakan bahasa yang sederhana dan mudah dipahami anak. Dengan begini, anak terbiasa untuk selalu menjaga lingkungannya. Jika kebiasaan baik ini diterapkan sampai mereka besar pasti akan menciptakan karakter yang kuat di dalam diri mereka.

\section{Peduli Sosial}

Untuk menanamkan jiwa sosial tersebut pada anak, orangtua harus lebih banyak melakukan praktik daripada hanya berteori sehingga anak anak akan mencontoh perbuatan - perbuatan nyata yang oranggtuanya lakukan. Banyak hal yang dapat dipraktikkan untuk menanamkan jiwa sosial pada anak, antara lain:

a. Mengajak anak sama - sama menengok saudara atau tetangga yang sedang sakit.

b. Mengajak anak sama - sama mengunjungi panti jompo.

c. Rutin bersedekah dan mengajarkan pentingnya bersedekah pada anak.

d. Beerbagi kebahagiaan dengan anak - anak jalanan, misalnya saat ulang tahun anak.

e. Berbagi makanan yang kita masak pada tetangga disekitar yang kurang mampu.

f. Mengajak anak untuk bersama - sama berbagi kebahagiaan dihari raya keagamaan dengan anak - anak di panti asuhan.

Beberapa contoh diatas merupakan sedikit saja dari apa yang bisa orangtua contohkan pada anak untuk tujuan mendidik anak agar memiliki jiwa kepedulian sosial yang tinggi.

9. Tanggung Jawab

Pembagian tugas rumah pada anak sangat baik untuk melatih sifat amanah dan menumbuhkan rasa tanggung jawab pada anak. Pembagian tugas pada anak ini menurut Salim (2013) dapat dilakukan dalam rangka menumbuhkan kepercayaan kepada anak agar bisa bertanggung jawab, dengan memberikan suatu tugas, amanah, pekerjaan tertentu, yang kemudian dikontrol kembali apakah tugas itu sudah dilaksanakan atau belum, sesuai apa tidak, baik ataupun tidak. Misalnya memberikan tugas kepada anak untuk mencuci piring, menyapu dan mengepel lantai dan pekerjaan lainnya yang bisa untuk dikerjakan oleh anak.

Demikianlah sembilan nilai yang disarankan untuk pendidikan karakter dalam keluarga beserta strategi internalisasi karakter pada anak di lingkungan keluarga. Selain itu, tetap diperlukan evaluasi yang dilakukan secara terus - menerus dan setiap saat untuk mengetahui samapai sejauhmana keberhasilan proses pendidikan karakter dan memperbaiki kekurangan yang ada supaya hasil selanjutnya menjadi lebih baik. Untuk itu orangtua perlu mengenal atau memperhatikan perkembangan watak anak - anak mereka. Idealnya mereka harus tahu tentang perkembangan jiwa anak.

Anak - anak adalah generasi yang akan menentukan nasib bangsa dikemudian hari. Karakter anak - anak yang terbentuk sejak dilingkungan keluarga akan sangat menentukan karakter bangsa dikemudian hari. Kaarakter anak - anak akan terbentuk dengan baik, jika dalam proses tumbuh kembang mereka sudah mendapatkan cukup ruang untuk mengepresikan diri secara leluasa. 
PEMBUDAYAAN NILAI KARAKTER DALAM KELUARGA DI DESA MADWAER KABUPATEN MALUKU TENGGARA KEC KEI KECIL BARAT

\section{Metode}

Penelitian ini menggunakan pendekatan penelitian yang bersifat kualitatif. Penelitian ini bertujuan untuk menggambarkan dan mempelajari masalah-masalah di dalam keluarga, satu bentuk tata cara yang berlaku dan yang berhubungan dengan pengetahuan, pemahaman, pandangan dan sikapsikap terhadap sebuah proses yang terjadi dari dan langsung di dalam keluarga.

Tipe penelitian ini dapat dipergunakan untuk memberi gambaran secara utuh dan menyeluruh tentang hal-hal yang ada kaitannya dengan pembudayaan nilai karakter dalam keluarga.

Penelitian ini berlokasi di Desa Madwaer dijadikan lokasi Penelitian berdasar pada pertimbangan bahwa pembudayaan nilai karakter di dalam keluarga mesti diterapkan serta ditanamkan oleh orang tua untuk perkembangan sikap dan karakter yang baik dalam diri anak.

Adapun sasaran dalam penelitian ini ialah semua anak dengan usia $11-17$ tahun di Desa Madwaer. Alasannya karena anak - anak di usia ini memiliki karakter yang kurang baik, dikarenakan kurang adanya peran orang tua terhadap pendidikan karakter anak - anak di usia tersebut. Sedangkan yang ditetapkan sebagai informan kunci dalam penelitian ini terdiri dari: Orang tua 10 orang, Anak usia 11 - 17 tahun, 8 anak.

\section{Teknik Pengumpulan Data}

Penelitian ini menggunakan beberapa teknik sebagai berikut : Observasi merupakan proses untuk memperoleh data dari tangan pertama dengan mengamati orang dan tempat pada saat dilakukan penelitian. Wawancara merupakan teknik pengumpulan data di mana pewawancara dalam pengumpulkan data mengajukan suatu pertanyaan kepada yang diwawancarai. Studi kepustakaan dimaksudkan untuk mendapatkan referensi yang membahas mengenai masalah yang diteliti. Penilitian melakukan kajian dari berbagai buku, nara sumber,dan masyarakat ditempat penelitian.

Teknik Analisa data yang dilakukan dengan beberapa teknik diantaranya: Reduksi Penggunaan reduksi data merupakan proses seleksi dan penyederhanaan data yang ada dalam catatan dalam lapangan dan proses dimaksud selama pelaksanaan penelitian. Sajian Data Semua informasi atau data yang telah direduksi, disusun dalam bentuk deskriptif kualitatif. Verifikasi dan penarikan kesimpulan, verifikasi telah ditentukan mulai dari tahap awal kumpulan data, reduksi data, sajian data, dan sampai tahap akhir penelitian yaitu penarikan kesimpulan

\section{Hasil Dan Pembahasan}

Pembudayaan nilai karakter sangatlah mendasar dalam membentuk karakter seorang anak dalam keluaraga. proses pembudayaan serta pewarisan nilai karakter dalam keluarga dimulai dari orang tua dan diterapkan kepada anak karena hal demikian merupakan hakekat dari pembudayaan itu sendiri, dimana orang tualah yang menjadi penununtun dalam membudayakan nilai karakter kepada anak. Selain itu juga pembudayaan serta pewarisan nilai karakter oleh orang tua kepada anak dalam keluarga suda dimulai sejak anak itu masih kecil sampai dewasa penerapan serta pembudayaan nilai karakter itu sudah dilakukan bahkan ada yang selalu melakukan dengan baik dan ada juga sebagian orang tua maupun anak belum melakukan dengan baik dengan melihat akan adanya perbedaan dari orang tua dulu-dulu dengan sebagian orang tua yang sekarang ini mereka selalu memberikan nasehat seperti halnya rajin menegur orang lain, menghargai orang yang lebih tua, bersikap sopan terhaadap siapa saja, meminta permisi, meminta terima kasih, itulah nasehat yang baik yang selalu ditanamkan oleh orang tua dulu-dulu dan dapat dipegang dan dilakukan juga oleh sebagian orang tua sekarang ini,berbeda dengan sebagian orang tua yang sekarang ini yang memang menerapkannya serta membudayakannya dari anak masih kecil sampai dewasa tapi tidak selalu melakukannya dengan baik

Keberhasilan dari proses pembudayaan nilai karakter kepada anak dalam keluarga sangatlah penting hal demikian terlihat jelas dari perubahan yang terjadi pada anak ketika ada anak yang sebagian orang tuanya menerapkan nilai karakter dalam hidupnya dengan baik sehingga meresponnya juga dengan baik dalam hal ini dapat memperbaiki karakternya. Sedangkan ada anak yang sebagian orang tuanya tidak menerapkan nilai karakter dengan maksimal dalam hal ini belum menasehati anak dengan baik disebabkan karena ada orang tua yang mengeluarkan kata-kata yang tidak pantas kepada anaknya sendiri ketika sedang memarahi anaknya, kemudian bersikap kasar terhadap anaknya juga sehingga dapat menyebabkan anak itu sendiri tidak merespon dengan baik dalam hal ini tidak dapat memperbaiki karakternya sehingga tidak ada perubahan karakter yang nampak pada dirinya. 


\section{Faktor-Faktor Pembudayaan Nilai Karakter}

Mempengaruhi

Pengaruh pembudayaan nilai karakter biasanya dimulai dari lingkungan terdekat kita yaitu salah satunya lingkungan keluarga sebelum anak akan terjun ke lingkungan masyarakat. Setiap anak pasti memiliki karakter yang berbeda-beda dalam bersikap dan bertindak. Pembentukan karakter pada seorang anak tentunya dipengaruhi oleh berbagai macam hal, baik itu lingkungan keluarga ataupun lingkungan tempat anak bersosialisasi. Akan tetapi faktor yang akan memberikan pengaruh dan dampak paling besar terhadap pembentukan karakter seorang anak adalah lingkungan terdekat anak yaitu keluarga.

Faktor-faktor yang mempengaruhi pembudayaan nilai karakter salah satunya adalah pengaruh lingkungan pergaulan yang menyebabkan sehingga anak menjadi nakal, malas, dan tidak dengar-dengaran terhadap orang tua. faktor lain yang mempengaruhi pembudayaan nilai karakter yaitu dari lingkungan keluarga disebabkan karena orang tua yang bersikap kasar kepada anaknya seperti memukul, mencubit, berteriak dengan keras, suka marah-marah, jarang ada waktu bersama anak di rumah sehingga itulah yang sangat mempengarhi karakter anak ketika keluar dari lingkungan keluarga dan bergaul di lingkungan masyarakat di situlah anak sering menunjukan karakter yang tercipta dan terbawa-bawa dari keluarga sampai kepada lingkungan di mana ia bergaul karena faktor dari lingkungan keluarga yang sangat mempengaruhi sikap anak sebab keluarga yang menjadi contoh jika orang tua menunjukan sikap yang baik maka anak juga akan mengikuti sama halnya dengan orang tua yang menunjukan sikap yang tidak baik maka anak juga melakukan yang tidak baik di luar lingkungan keluarga, sehingga dapat dikatakan bahwa lingkungan keluarga menjadi sorotan dalam mempengaruhi pembudayaan nilai-nilai karakter dalam membentuk sikap yang baik.

Sebab semuanya yang baik yang diajarkan dimulai dari dalam keluarga. pembudayaan nilai karakter dalam keluarga tidak terlepas pisahkan dari pendampingan orang tua dalam meluangkan waktu untuk membentuk karakter anaknya, karena anak membutuhkan arahan dari orang tua sebagai wujud dari pembudayaan itu sendiri maka pembudayaan nilai karakter dikatakan berhasil disebabkan karena adanya peran orang tua dalam hal meluangkan waktu dengan anak-anaknya. Namun ternyata orang tua tidak selalu dan jarang punya waktu bersama dengan anak-anak di rumah disebabkan karena kesibukan kerja dan pergi ke kebun sampai sore baru kembali, pergi berjualan di pasar, ada orang yang datang bertamu duduk cerita sehingga waktuwaktu bersama anak jarang, tetapi adajuga orang tua yang memang selalu meluangkan waktunya bersama anak di rumah walaupun ditengah kesibukannya untuk bekerja tapi selalu mengingatkan anak-anak untuk makan, belajar, dan lonceng berbunyi selalu mengingatkan anaknya untuk pergi beribadah. Itulah nilai pembudayaan yang perlu diingatkan dan secara terus menerus diperhatikan oleh setiap orang dalam keluarga.

\section{Bentuk Pembudayaan Nilai Karakter Terkikis.}

Sembilan nilai yang disarankan untuk pendidikan karakter beserta strategi internalisasi karakter pada anak dalam lingkungan keluarga yaitu nilai Religius, Jujur, Toleransi, Disiplin, peduli sosial, demokratis, mandiri, peduli lingkungan dan tanggung jawab. nilai-nilai karakter yang biasanya di budayakan atau memiliki pengertian bahwa diterapkan oleh orang tua dalam keluarga di Desa Madwaer diantaranya adalah nilai Religus, Jujur, Toleransi, dan Disiplin yang dianggap penting dan menjadi dasar dalam membentuk karakter seseorang dengan baik sebab generasi sekarang ini tidak lagi memaknai nilai-nilai itu dengan baik sehingga orang tua dalam keluarga terus berusaha untuk selalu menerapkan nilai-nilai karakter itu dengan baik agar nilai-nilai itu tetap dipegang dan dilakukan dengan sebaik mungkin oleh anak-anak di generasi sekarang ini bahkan juga kepada orang tua supaya nilai-nilai karakter itu tidak hilang begitu saja, sehingga peroses pembudayaan itu tetap terus berlangsung sebab bagi mereka nilai religius yang mereka utamakan menayangkut dengan ibadah terus diingatkan sebab ada orang tua dan anak-anak sekarang ini sangat malas untuk pergi beribadah walaupun sudah dengar bunyi lonceng tapi tetap acuh terhadap suara lonceng, sehingga bagi mereka ibadah menjadi prioritas utama dimana mereka sedang beraktivitas dan ibadah merupakan dasar pembentukan iman seseorang terutama bagi anak dalam keluarga, selain itu kejujuran sangat penting karena anak-anak sekarang ini suka belajar berbohong, kemudian disiplin dan toleransi juga perlu untuk mereka terapkan dengan baik sebab anak-anak sekarang ini tidak tahu mengahargai orang yang lebih tua, bahkan orang tua sendiri saja tidak dihargai, tidak tahu sopan santun sehingga nilai-nilai itu yang perlu untuk diterapkan dengan baik bagi anak-anak di dalam keluarga. 
PEMBUDAYAAN NILAI KARAKTER DALAM KELUARGA DI DESA MADWAER

Berbagai respon dari anak-anak terhadap nilai karakter yang diterapkan oleh orang tua kepada mereka ada yang merespon dengan baik dalam hal ini melakukan seperti yang disampaikan oleh orang tua mereka tetapi sebaliknya ada sebagian anak yang tidak meresponya dengan baik dalam hal ini melanggar apa yang orang tua mereka terapkan sehingga dapat dikatakan bahwa sifat dari masingmasing anak itu berbedah, artinya ada yang penurut ada pulah yang tidak. Berdasarkan realita ini maka dapat dikatakan bahwa untuk memperoleh respon anak yang baik dalam menjalankan nilai karakter yang dibudayakan oleh orang tua kepada mereka haruslah di lakukan proses pembudayaan secara terus-menerus sehingga dapat membentuk karakter anak itu sendiri sekalipun tidak semua arahan yang diberikan oleh orang tua dapat diikuti oleh seorang anak. Proses pembudayaan itu harus terus dilakukan dan diterapkan di dalam keluarga agar nilai-nilai dalam budaya setempat terus di jaga dan dihargai karena dengan adanya pembudayaan nilai-nilai karakter yang diterapkan di dalam keluarga dapat menjadikan karakter seseorang dengan baik.

\section{Relevansi Nilai Karakter Dalam Keluarga Bagi Pemgembangan Pak}

Nilai karakter berhubungan erat dengan PAK karena di dalamnya terdapat nilai-nilai yang baik untuk membentuk kehidupan seseorang dalam melakukan hal-hal yang baik. Pendidikan Agama Kristen adalah pendidikan yang sangat penting, sebab pendidikan agama Kristen adalah pendidikan yang memberikan landasan iman Kristen kepada setiap orang baik melalui, keluarga, gereja dan sekolah. E.G Homrighousen dalam Budiyana (2011) mengemukakan bahwa yang dimaksudkan dengan Pendidikan Agama Krsiten adalah usaha sadar gereja dalam mendidik anak didiknya dalam rangka pewarisan iman kristen dengan segala kebenarannya, sebagaimana yang dinyatakan dalam Alkitab dan melatih mereka untuk hidup harmonis sesuai dengan iman Kristen, supaya mereka menjadi anggota gereja yang dewasa yang menyadari dan menyakini imannya dan menyatakannya dalam praktek sehari-hari. Pendidikan Agama Kristen (PAK) pada dasarnya dapat membantu manusia, untuk menjadi manusia yang bertanggungjawab ditengah kehidupan keluarga, bergereja dan berbangsa. Selain itu Menurut FC. Lewir dalam (Tarumasely, 2001) PAK adalah suatu tugas pelayanan yang diberikan TUHAN kepada umatNya di zaman perjanjian lama dan kini oleh Yesus Kristus kepada gereja di zaman Perjanjian Baru,
KABUPATEN MALUKU TENGGARA KEC KEI KECIL BARAT untuk membina, mendidik, mengasuh, mengajar, mempersiapkan, melatih dan melengkapi semua orang dengan dukungan iman, pengharapan dan kasih melalui hidup, perkataan dan perbuatan dari zaman ke zaman di segala tempat dari generasi ke generasi sampai kepada akhir zaman.

Nilai-nilai karakter yang di terapkan oleh orang tua dalam keluarga di Desa Madwaer memiliki hubungan dengan Pendidikan Agama Kristen ( PAK ) yakni Nilai religius, kejujuran, toleransi, dan disiplin. Nilai-nilai ini memiliki hubungan dengan PAK karena Pendidikan Agama Kristen mendidik seseorang untuk melakukan halhal yang baik dan selebihnya adalah membentuk iman seseorang untuk terus bertumbuh dalam pengenalan akan Kristus.

oleh sebab itu dapat dikatakan bahwa penerapan nilai-nilai karakter dalam keluarga tidak terlepas pisahkan dari Pendidikan Agama Kristen ( PAK ). Pendidikan Agama Kristen ( PAK ) memiliki hubungan yang kuat dalam menerapakan nilai-nilai karakter dalam keluarga kerana di dalam konten PAK itu sendiri yang dikemas untuk mendidik dan membentuk kepribadian soseorang menjadi pribadi yang baik sejak anak itu lahir sampai sampai ia menjadi dewasa. Hal ini yang menjadi pegangan bagi orang tua untuk membudayakan nilai-nilai karakter kepada anak. Dengan demikian aspekaspek yang perlu diperhatikan oleh orang tua adalah seperti kesediaan untuk menerima tugas dan tanggungjawab mendidik anak haruslah lebih ditekankan pada kesadaran dalam meningkatkan nilai-nilai karakter, mengasihi sesama dengan Tuhan, taat dan patuh kepada perintah dan ajaran Tuhan, sehingga dari situlah anak akan bertumbuh menjadi manusia yang hidup dalam pengenalan akan kasih TUHAN. Maka orang tua harus dengan penuh kasih mendidik anak di rumah dalam pengenalan akan Yesus Kristus, karena Dialah guru yang sesungguhnya, seperti ada tertulis dalam Ibrani 12:10. "Sebab mereka mendidik kita dalam waktu yang pendek sesuai dengan apa yang mereka anggap baik, tetapi Dia menghajar kita untuk kebaikan kita, supaya kita beroleh bagian dalam kekudusan-Nya". Firman Tuhan ini memberi makna bahwa sebagai orang tua memiliki tugas untuk membentuk karakter Anak dengan hal-hal baik, maka didalam diri orang tua tersebut tercermin rasa tanggung jawab yang tinggi untuk mendukung anaknya dalam setiap pengembangan diri anak. Masa depan anak merupakan alasan dan prioritas dari proses pendidikan yang dimulai dari rumah atau keluarga, dimana orang tua memiliki peran penting 
serta penuh rasa tanggung jawab dalam menerapkan nilai-nilai karakter. Hal ini berhubungan dengan Amsal 19:20..."Dengarkanlah nasihat dan terimalah didikan, supaya engkau menjadi bijak di masa depan". Kebijakasanaan akan terbentuk salah satunya lewat proses pendidikan, karena lewat pendidikan inilah anak membentuk karakter yang baik dan benar demi masa depannya. Pada umumnya keberhasilan anak juga merupakan sukacita dan keberhasilan orang tua di rumah. Dengan begitu, maka tugas dan tanggung jawab sebagai orang tua harus dilaksanakan dengan benar dengan menerapkan nilai-nilai karakter kepada anak. Kegagalan anak, juga merupakan kegagalan orang tua dalam menjalankan tugas dan panggilannya. Hal ini sehubungan dengan Amsal 29:17..."Didiklah anakmu, maka Ia akan memberikan ketenteraman kepadamu, dan mendatangkan sukacita kepadamu". Hal ini merupakan gambaran hubungan antara orang tua dan anak. Dimana keberhasilan seorang anak pada dasarnya tergantung dari orangtuanya sendiri.

\section{Simpulan}

Bentuk-bentuk pembudayaan nilai karakter dalam keluarga di Madwaer ditemui bahwa pewarisan nilai karakter dalam keluarga dapat dipahami oleh orang tua dan anak melalui sikap hidup, cara hidup, serta sifat dan perilaku seseorang yang ditunjukan kepada orang lain. Hal ini merupakan langkah awal dari proses pembudayaan nilai karakter itu sendiri, karena pembudayaan yang memiliki akar kata " budaya " adalah suatu pengetahuan dan pemahaman terhadap sesuatu yang muncul dari dalam diri masing-masing orang secara lahiria yang diperbiasakan, dijaga, dan dilestarikan, sehubungan dengan cara hidup, sikap hidup, sifat dan perilaku yang ditunjaukan oleh seseorang dalam keluarga.

Pewarisan nilai karakter dalam keluarga dimulai dari orang tua dan diterapkan kepada anak karena hal demikian merupakan hakekat dari pembudayaan itu sendiri, dimana orang tualah yang menjadi penununtun dalam membudayakan nilai karakter kepada anak. Selain itu juga pembudayaan serta pewarisan nilai karakter oleh orang tua kepada anak dalam keluarga suda dimulai sejak anak itu masih kecil sampai dewasa penerapan serta pembudayaan nilai karakter itu sudah dilakukan bahkan ada yang selalu melakukan dengan baik dan ada juga sebagian orang tua maupun anak belum melakukan dengan baik. Oleh sebab itu diharapkan setiap orang tua haruslah betul-betul menerapakan nilai karakter yang baik kepada anak dengan dimulainya menasehati anak dari kecil hingga anak sudah dewasa pembudayakan nilai karakter itu tetap dilakukan dan terus diwariskan dengan baik secara turun temurun kepada anak-anak dimana anak itu diajar untuk bagaimana ia bisa memiliki karakter yang baik dari sikap, tutur kata, maupun perilaku anak itu setiap hari.

Di dalam pewarisan nilai karakter terlihat adanya perubahan karakter dari anak-anak di Madwaer ada yang perubahan karakternya sudah baik, dan ada sebagian besar yang belum baik, disebabkan karena adanya faktor-faktor yang mempengaruhi pembudayaan nilai karakter dalam keluarga di desa Madwaer adalah faktor dari lingkungan keluarga yang paling utama barulah ke lingkungan pergaulan atau masyarakat disebabkan karena orang tua yang bersikap kasar kepada anaknya. Karena, faktor dari lingkungan keluarga sangat mempengaruhi sikap anak sebab keluarga yang menjadi contoh jika orang tua menunjukan sikap yang baik maka anak juga akan mengikuti, sama halnya dengan orang tua yang menunjukan sikap yang tidak baik maka anak juga melakukan yang tidak baik di luar lingkungan keluarga. Sehingga dapat dikatakan bahwa lingkungan keluarga menjadi sorotan dalam mempengaruhi pembudayaan nilai-nilai karakter dalam membentuk sikap yang baik. Dari faktor-faktor itulah maka dapat dikatakan bahwa proses pembudayaan nilai karakter dalam keluarga tidak terlepas pisahkan dari pendampingan orang tua dalam meluangkan waktu untuk membentuk karakter anaknya, karena anak membutuhkan arahan dari orang tua sebagai wujud dari pembudayaan itu sendiri maka pembudayaan nilai karakter dikatakan berhasil disebabkan karena adanya peran orang tua dalam hal meluangkan waktu dengan anak-anaknya.

Akan tetapi pada kenyataannya sebagian besar orang tua di Madwaer tidak selalu dan jarang punya waktu bersama dengan anak-anak di rumah disebabkan karena kesibukan kerja. Kemudian ditinjau dari segi pembudayaan nilai karakter yang selalu diterapkan orang tua dalam keluarga ternyata, nilai-nilai yang menjadi fokus dalam menerapkan dan melakukan dalam keluarga yaitu nilai religius, jujur, disiplin dan toleransi. Nilai-nilai tersebut mengalami pengikisan yang disebabkan karena karakter yang tidak baik yang ditunjukan oleh orang tua maupun anak dalam lingkungan keluarga di Madwaer, sehingga nilai-nilai itu terus-menerus diterapkan dan diajarkan terutama kepada anak-anak di dalam keluarga. Respon dari anak-anak terhadap pembudayaan nilai karakter yang diterapkan oleh 
PEMBUDAYAAN NILAI KARAKTER DALAM KELUARGA DI DESA MADWAER

orang tua kepada anak-anak mereka hanya ada sebagian anak di Madwaer yang merespon dengan baik dan ada sebagian besar anak yang tidak merespon dengan baik.

Ditinjau dari peran dan tanggung jawab orang tua dan anak-anak di desa Madwaer terhadap pembudayaan nilai karakter dalam keluarga maka sebagian besar orang tua belum melakukan tugas dan tanggung jawabnya dengan baik, artinya bahwa peran orang tua dalam menerapkan dan melakukan tugas dan tanggung jawab dalam mendidik, membimbing, menasehati anak di rumah belum melakukannya dengan maksimal sehingga mendidiknya masih stengah-stengah atau belum sepenuhnya baik. Dan bagi anak-anak juga demikian belum melakukan dengan baik dan belum maksimal.

Terkait dengan relevansi nilai-nilai karakter dalam keluarga di desa Madwaer terhadap PAK, di temui bahwa nilai karakter ada hubungannya dengan PAK dimana keduanya saling berhubungan menanamkan dan memberikan serta mengajarkan nilai yang baik kepada setiap orang agar tetap melakukannya dengan baik, dan telah diketahui bahwa Nilai-nilai karakter yang di terapkan oleh orang tua dalam keluarga di Desa Madwaer memiliki hubungan dengan Pendidikan Agama Kristen ( PAK ) yakni Nilai religius, kejujuran, toleransi, dan disiplin. Nilai-nilai ini memiliki hubungan dengan PAK karena Pendidikan Agama Kristen mendidik seseorang untuk melakukan halhal yang baik dan selebihnya adalah membentuk iman seseorang untuk terus bertumbuh dalam pengenalan akan Kristus. oleh sebab itu dapat dikatakan bahwa penerapan nilai-nilai karakter dalam keluarga tidak terlepas pisahkan dari Pendidikan Agama Kristen ( PAK ).

\section{Ucapan Terima Kasih}

Penulis menyampaikan terima kasih kepada warga desa Madwaer kabupaten Maluku Tenggara Kecamatai Kei Kecil Barat, yang bersedia menerima penulis untuk melakukan penelitian. Terima Kasih untuk setiap keluarga yang bersedia dengan senang hati menerima penulis dan membantu menjawab pertanyaan-pertanyaan yang diberikan, sehingga akhirnya penulis dapat menyelesaikan tulisan ini.

\section{Pustaka Acuan}

Conny R. Semiawan. (2007). Perkembangan dan belajar peserta didik. Jakarta: 2007

Depdikbud Dirjen Pendidikan Tinggi Proyek Pendidikan Guru Sekolah Dasar.
KABUPATEN MALUKU TENGGARA KEC KEI KECIL BARAT

E. Adamson Hoebel, "Enkulturasi" dalam https://id.wikipedia.org/wiki. Kamis, 10 Oktober 2019

FC. Lewir dalam Tarumaseley Els, Pendidikan Agama Kristen Orang Dewasa, 2001.

Hardi Budiyana. Dasar-Dasar Pendidikan Agama Krsiten. (Karanganyar. Berita Hidp Seminari. 2011.

Hassan Shadily, 1980. Ensiklopedia Indonesia,jilid 3, Jakarta: Ichtiar Baru-Van Hoeve.

Herskovits. Antropologi Pendidikan: Suatu Pengantar, dalam Jurnal Antropologi, Tahun V, Nomor 7, Januari-Juni 2004, Laboratorium Antropologi Jurusan Antropologi FISIP Universitas Andalas.

Imran Manan, PhD. Antropoligi Pendidikan Suatu Pengantar. Depdikbud, Jakarta: 1989

Moh. Haitami Salim, Pendidikan Agama Islam dalam Keluarga: Refitalisasi Peran Keluarga dalam Menyiapkan Generasi Bangsa yang Berkarakter. Arruzz Media, Yogyakarta: 2013,

Rafael Raga Maran, “ Manusia dan Kebudayaan " Dalam Perspektif Ilmu Budaya Dasar. Penerbit Rineka CIpta, Jakarta: 2007, hlm. 23.

Sutarjo Adisusilo, Pembelajaran Nilai - Karakter Konstruktivisme dan VCT Sebagai Inovasi Pendekatan Pembelajaran Afektif . Penerbit Rajawali Pers Jakarta : 2014.

Sutarjo Adisusilo, Pembelajaran Nilai - Karakter Konstruktivisme dan VCT Sebagai Inovasi Pendekatan Pembelajaran Afektif . Penerbit Rajawali Pers Jakarta : 2014

Syamsul Kurniawan, Pendidikan Karakter: Konsepsi dan Implementasinya Secara Terpadu di Lingkungan Keluarga, Sekolah, Perguruan Tinggi dan Masyarakat. Penerbit Ar - Ruzz Media, Yogyakarta : 2013

Syamsul Kurniawan, Pendidikan Karakter: Konsepsi dan Implementasinya Secara Terpadu di Lingkungan Keluarga, Sekolah, Perguruan Tinggi dan Masyarakat. Penerbit Ar - Ruzz Media, Yogyakarta 